\title{
Ecosystem engineering by hummock-building earthworms in seasonal wetlands of eastern South Africa: Insights into the mechanics of biomorphodynamic feedbacks in wetland ecosystems
}

\author{
Michael C. Grenfell, ${ }^{1 *}$ (D) Rolf Aalto, ${ }^{2}$ Suzanne E. Grenfell ${ }^{3}$ and William N. Ellery \\ ${ }^{1}$ Institute for Water Studies, Department of Earth Science, University of the Western Cape, Bellville, South Africa \\ ${ }^{2}$ Geography, College of Life and Environmental Sciences, University of Exeter, Exeter, UK \\ 3 Department of Geography, Environmental Studies and Tourism, University of the Western Cape, Bellville, South Africa \\ ${ }^{4}$ Department of Geography, Rhodes University, Grahamstown, South Africa
}

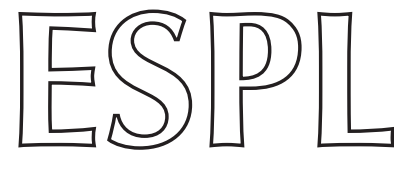

Earth Surface Processes and Landforms

\begin{abstract}
This paper resolves the origin of clay hummock micro-topography in seasonal wetlands of the Drakensberg Foothills, providing a review and appraisal of previously-suggested mechanisms of hummock formation in the context of new field and laboratory data. Field surveys revealed neo-formation of clay hummocks in a river channel that had been abandoned in c.1984. Fresh earthworm castings were located atop hummocks protruding from inundated abandoned channel margins. Earthworm castings, and sediment cores taken in hummocks and adjacent hollows, were analysed for soil-adsorbed carbon and nitrogen using an $\mathrm{HCN}$ analyser, and for ${ }^{210} \mathrm{~Pb}$ activity using alpha-geochronology. ${ }^{210} \mathrm{~Pb}$ activity profiles suggest relative enrichment of the isotope in hummocks, and relative depletion in adjacent hollows. Earthworm castings are characterised by very high ${ }^{210} \mathrm{~Pb}$ activity, as well as high $\mathrm{C}$ and $\mathrm{N}$ contents. Hummocks have significantly higher $\mathrm{C}$ and $\mathrm{N}$ contents than adjacent hollows. Results suggest that it is the foraging activity of earthworms in litter-rich seasonal wetland hollows, and repeated excretion of castings atop adjacent hummocks, that is responsible for the elemental enrichment observed. The paper presents a conceptual model of hummock formation in wetlands through interactions between hydrogeomorphology and earthworm activity, and illustrates a mechanism of biogeomorphic inheritance through which ordered patterns of preferential flow can emerge in ecosystems. Further implications of hummock formation and nodal accumulation of nutrients are considered in relation to wetland resilience and regulatory ecosystem service provision. (c) 2018 John Wiley \& Sons, Ltd.
\end{abstract}

KEYWORDS: biogeomorphology; zoogeomorphology; biopedoturbation; wetlands in drylands; ecosystem services

\section{Introduction}

A large proportion of research on zoogeomorphology and biopedoturbation has centred on understanding the geomorphic and biogeochemical work of burrowing and soil foraging animals (Whitesides and Butler, 2015; Coombes, 2016; Coggan et al., 2018, for reviews). Although these animals conduct their activities at the geomorphological micro-scale, the cumulative effect of colonies or populations can create distinctive landscapes (Zaitlin and Hayashi, 2012; Coombes and Viles, 2015). The micro-landforms produced by burrowing and soil foraging activities have a patchy distribution that creates gradients of local environmental change (Zaitlin and Hayashi, 2012), can affect the flow paths of moisture and other resources (Eldridge et al., 2010), and can create refugia for plant germination (Whitesides and Butler, 2016). Through burial of vegetation by burrow spoil or casting material (Zaitlin and Hayashi, 2012), provision of foraging pits that provide conditions favouring enhanced litter decomposition (Travers and Eldridge, 2016), or selective transport and concentration of organic materials, burrowing and soil foraging animals can profoundly influence the structure and biogeochemistry of soil environments (Coggan et al., 2018), and thereby increase landscape-scale heterogeneity and biodiversity (Zaitlin and Hayashi, 2012).

In wetlands, which mark the transition from terrestrial to aquatic conditions, the species of plants and animals that occur have developed adaptations to living in a variably anoxic and thus biologically-challenging edaphic environment (Mitsch and Gosselink, 2008). With the necessary adaptations in place, 
these species are able to thrive on the excess available moisture defining wetland soils, resulting in relatively rapid gains in biomass which, through various interactions with physical processes of sediment and solute flux, leads to structural and functional ecosystem complexity (Tooth and McCarthy, 2007; Ellery et al., 2009; Tooth, 2018). The juxtaposition of constraint and opportunity in wetland systems has in some cases led to ecologically ingenious functions or behaviour by biota that shapes habitat in ways that influence their and other species' persistence (i.e. ecosystem engineering, after Jones et al., 1994). Examples include dam building by beavers (Jones et al., 1994), distributary channel development by hippopotami (McCarthy et al., 1998), co-evolution of riparian vegetation and fluvial style (Davies and Gibling, 2011; Corenblit et al., 2015), and modification of topography (Darwin, 1881; Fey, 2010) and biogeochemistry (Jouquet et al., 2006; Barot et al., 2007) by burrowing earthworms. These examples illustrate the argument of Jones et al. (1997), that organisms that modify hydro-edaphic environments tend to have large scale ecosystem-level effects because water, soil and sediments tend to integrate many ecological resources within one locale, and so the effects of modifying them are widely broadcast.

This paper considers the origin of clay hummock microtopography (Figure 1) in seasonal wetlands of the Drakensberg Foothills, which has been a subject of local fascination for scientists working on various aspects of the wetlands' ecology and geomorphology. Downing (1966) attributed the origin of hummocks to trampling by cattle, an interpretation refuted by Longmore (2001) primarily because hummocks also occur in wetlands that have been protected from cattle grazing. Longmore (2001) suggested that hummock micro-topography may result from water eroding (slowly) around vegetation tufts, but did not elaborate on the potential mechanism involved. Differences in vegetation on hummocks (grasses) and in interhummock hollows (sedges) have been noted by Begg (1989), Guthrie (1996), and Kotze and O'Connor (2000), the latter two studies attributing this to differences in hydroperiod (frequency and duration of inundation; Mitsch and Gosselink, 2008) between hummock surfaces and inter-hummock hollows.

Following observation of an abundance of earthworms within hummocks, and aggregates of earthworm castings in tussocky vegetation, Kotze and $\mathrm{O}^{\prime}$ Connor (2000) proposed that earthworm activity may contribute to hummock formation, and offered the additional alternative hypothesis that the hummocks are formed by freeze-thaw processes (i.e. that they may be thufur features produced by localised displacement of surface soil material due to seasonal frost penetration; Grab, 1994). These ideas are formally evaluated in this paper within a theoretical framework that recognises two-way biomorphodynamic feedbacks in biogeomorphic systems
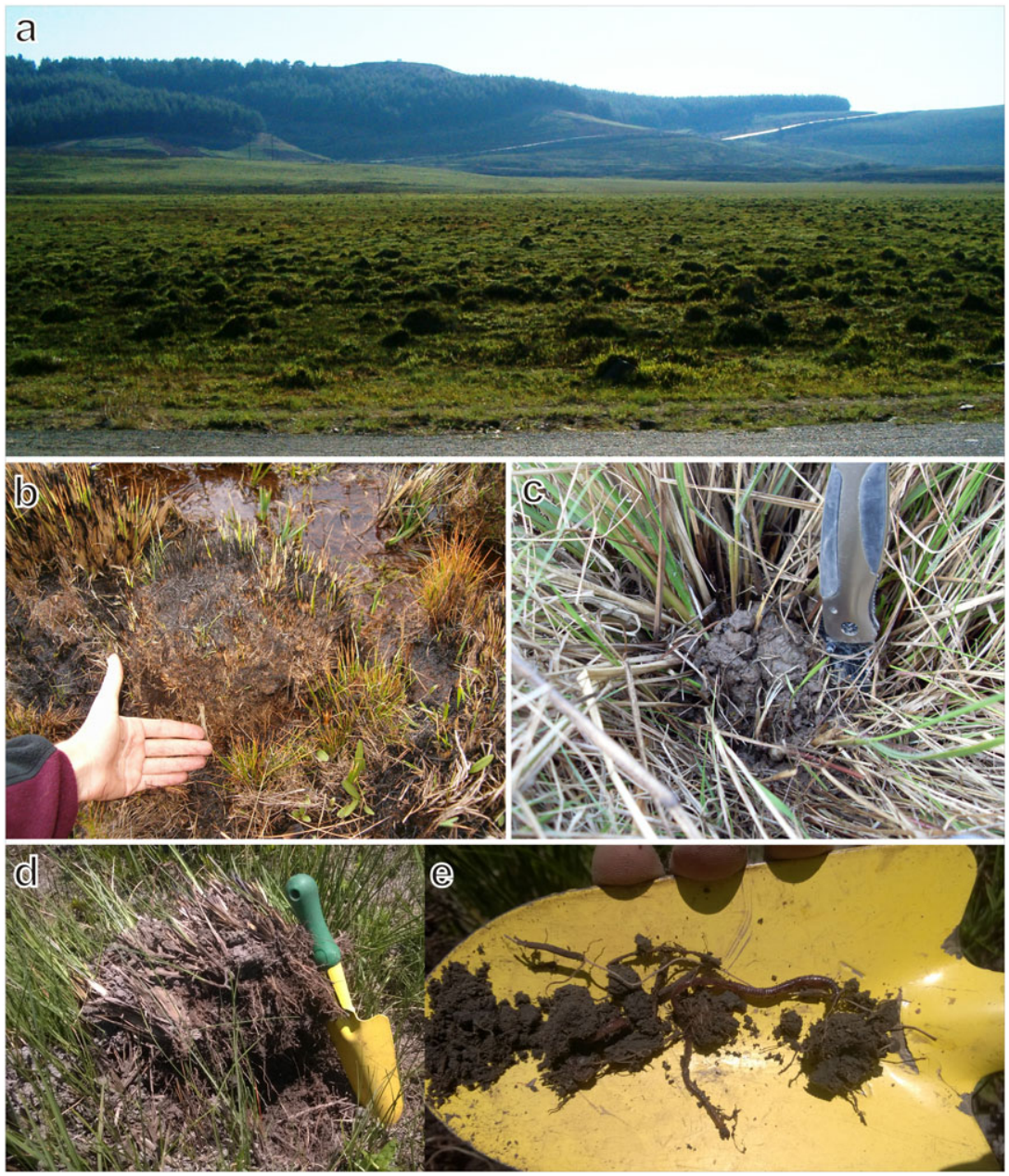

Figure 1. Photographs of hummocks in wetlands of the KwaZulu-Natal Drakensberg Foothills, showing (a) clay hummock micro-topography in a seasonally-inundated floodplain wetland at Hlatikulu Vlei, (b) typical clay hummock form in a seasonally-inundated valley-bottom wetland at Stillerust Vlei, (c) fresh earthworm castings atop a grass-covered clay hummock located at the margin of an abandoned channel on the floodplain of the Nsonge River at Hlatikulu Vlei, (d) an upturned hummock with a dry casting-covered surface and high-moisture root mesh interior, from the wetland shown in (a), and (e) juveniles of Proandricus richerti recovered from the root mesh of the hummock pictured in (d). Wetland locations are indicated in Figure 2. [Colour figure can be viewed at wileyonlinelibrary.com] 
(Murray et al., 2008), and co-evolution of landforms and biological communities (Reinhardt et al., 2010). The paper seeks to elucidate the underlying mechanisms of hydrogeomorphiczoogeomorphic feedback that shape the clay hummock micro-topography evident in numerous wetlands across the Drakensberg Foothills of eastern South Africa, and presents a conceptual model of hummock formation by earthworm activity developed with reference to field survey and laboratory biogeochemical and radionuclide data. The paper considers further implications of the observed earthworm activity for wetland micro-topographic reticulation, preferential flow path development, and resource distribution (Coggan et al., 2018), the affected wetland regulatory ecosystem services, and wetland resilience (after Tooth, 2018).

\section{Regional setting}

The Drakensberg Mountains comprise a high-elevation swath of Drakensberg Group basalt overlying sandstones, siltstones and mudstones of the Karoo Supergroup (Figure 2, Frame A). The 'High Drakensberg' forms part of the Great Escarpment which locally marks the border between the KwaZulu-Natal province of South Africa, and Lesotho, and comprises basalt peaks that reach elevations of $\sim 3500 \mathrm{~m}$ asml, and a westward-sloping plateau at $\sim 3000 \mathrm{~m}$ amsl. The Drakensberg Foothills radiate east- and southeast-ward of the Great Escarpment through an elevation range of $1800-1400 \mathrm{~m}$ amsl, and are underlain by Karoo Supergroup sedimentary rocks that are extensively intruded by dolerite dykes and sills.

The wetlands in the Drakensberg Foothills considered in this study (Figure 2, Frame A) are underlain by Tarkastad Subgroup fine-grained sedimentary rocks (mudstones, siltstones, finegrained sandstones), or weathered dolerite (Dartmoor Vlei). Many of these wetlands are situated in broad valleys upstream of dolerite intrusions, which have acted to locally impede river incision, and force lateral planation of the less resistant valleyfloor sedimentary rocks (Tooth et al., 2002, 2004; Grenfell et al., 2008). The associated development of meandering river floodplains has in some cases impounded tributary valleys, leading to the formation of blocked-valley wetlands (Grenfell et al., 2008, 2009, 2010).

Floodplain and valley-bottom wetlands in the Drakensberg Foothills host 2-5 m thick accumulations of clay-rich sediment, which is derived predominantly through the weathering of basalt, dolerite, and clay-rich sedimentary rocks (both locally and in the upstream catchment). The sediment overlies a $0.1-$ $0.2 \mathrm{~m}$ thick layer of planation-produced gravel and weathered bedrock (Grenfell et al., 2008, 2009). In the floodplain wetlands, the upward-fining basal-gravel to clay sequence is considered a product of lateral accretion associated with slow lateral migration by a meandering channel (Tooth et al., 2002). In the steeper valley-bottom wetlands with low-order inflowing channels, similar upward-fining sequences are associated with gully-floodout processes, with bedrock planation occurring through gully incision (Grenfell et al., 2009). In the vicinity of floodouts, upward-fining sequences punctuated by sand lenses are a consequence of long-term switching between proximal and distal-floodout deposition processes driven by spatio-temporal variation in gully development (Grenfell et al., 2009).

Most wetlands of the Drakensberg Foothills fall within the 'Sub-Escarpment Grassland Bioregion' units Gs 10 (Drakensberg Foothill Moist Grassland) or Gs 12 (East
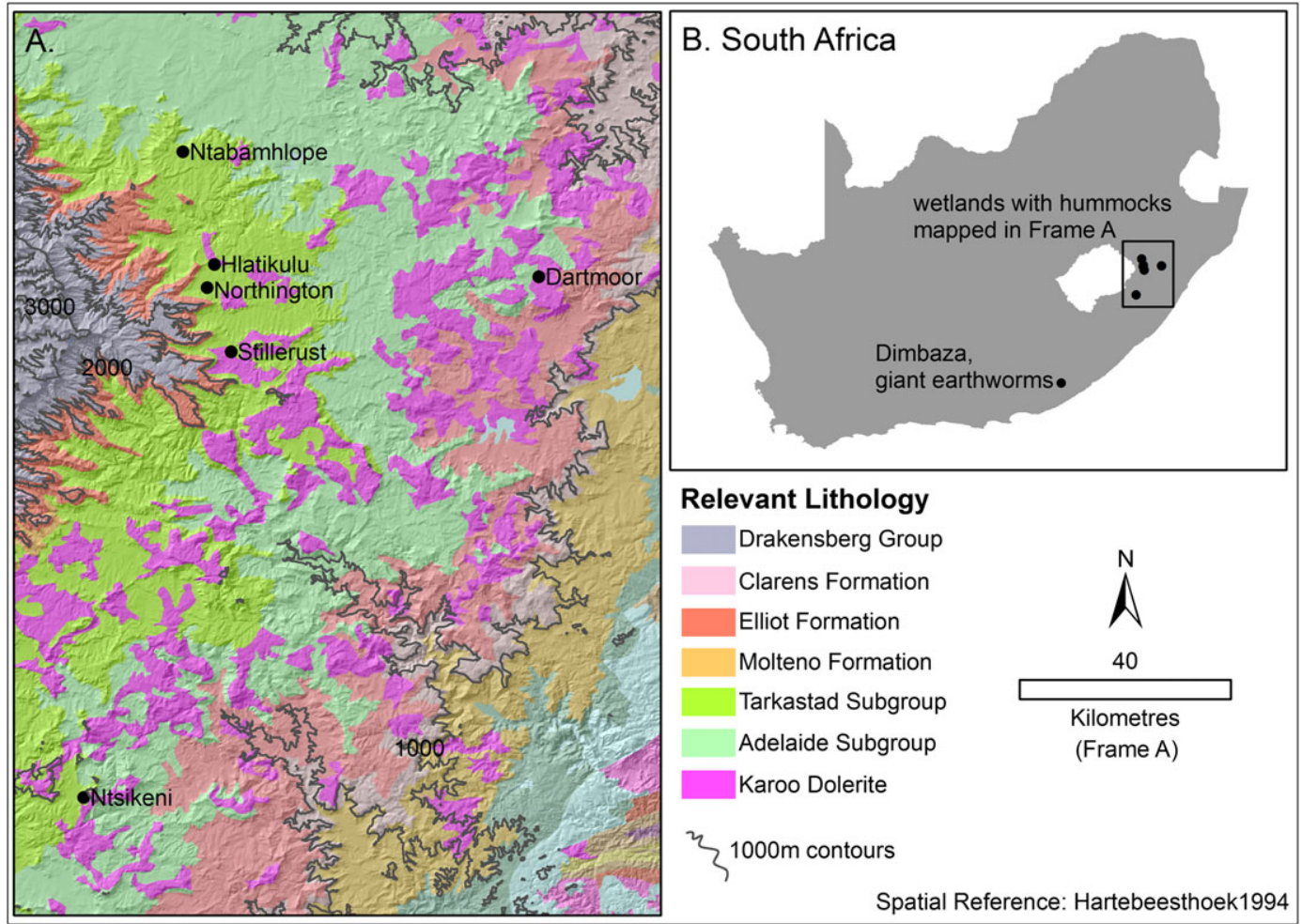

Figure 2. Spatial distribution of wetlands known by the authors to host clay hummock micro-topography (not an exhaustive list). Hlatikulu and Northington form the focus of field investigations conducted for this paper. Other wetlands indicated in Frame A have formed the focus of geomorphological research and/or restoration planning assessments by the authors (see text for publication details). Dimbaza indicated in Frame B is an area known for the development of large hummocks in seasonal wetland environments, associated with the activity of giant earthworms (Fey, 2010), and is included here to broaden the discussion. Karoo Supergroup lithologies underlying or located in the catchment of these wetlands are included in the legend (CGS, 2017). Additional regional biophysical characteristics of the wetlands are summarised in Table I. [Colour figure can be viewed at wileyonlinelibrary.com] 
Griqualand Grassland), while most of the High Drakensberg wetlands fall within the 'Drakensberg Grassland Bioregion' units Gd 8 (Lesotho Highland Basalt Grassland) or Gd 10 (Drakensberg Afroalpine Heathland) (Mucina and Rutherford, 2006). The wetlands themselves are monocot-, and particularly graminoid-dominated systems, hosting a diversity of species within families such Poaceae, Cyperaceae, Juncaceae, and Typhaceae, distributed along altitudinal and soil wetness gradients (Kotze and O'Connor, 2000; Sieben et al., 2010). Terrestrial grassland hillslopes typically grade gradually toward the wetter valley floor environments through grass-dominated temporary wetland, grass/sedge dominated seasonal wetland, and sedge/rush/reed dominated permanent to semi-permanent wetland (Kotze and O'Connor, 2000; Sieben et al., 2010).

Biophysical characteristics of the vegetation units described above are summarised in Table I for comparison. The Foothills and High Drakensberg regions are similar in terms of mean annual precipitation (Table I), rainfall intensity and annual erosivity (Vrieling et al., 2010), although a greater proportion of the precipitation in the High Drakensberg is expected to fall as snow. The regions have the same annual atmospheric water balance (AI: Dry subhumid), but differ substantially in terms of mean annual temperature and mean frost days, the High Drakensberg being much colder than the Drakensberg Foothills. Summary data for the Dimbaza area of the Eastern Cape (Figure 2, Frame B) are included in Table I for comparison

Table I. Summary of regional biophysical characteristics of the wetlands mapped in Figure 2. Equivalent characteristics for wetlands in the High-Drakensberg Mountains hosting microtopographic features of freeze-thaw origin (thufur; Grab, 1994) are included in this table for comparison and later discussion

Central/Southern Drakensberg Foothills (Ntabamhlope, Hlatikulu, Northington, Stillerust, Ntsikeni) and Karkloof Plateau (Dartmoor)

Underlying Lithology ${ }^{1}$ : Tarkastad Subgroup; mudstone, fine to medium grained sandstone. Karoo Dolerite (Dartmoor).

Elevation ${ }^{2}$ : 1400-1800 m amsl

Climate $^{3}$ : MAP (779-887 mm), MAE (1638-1658 mm), Al (0.51; Dry subhumid), MAT $\left(14.6-14.7^{\circ} \mathrm{C}\right)$, MFD (26-30).

Vegetation Types ${ }^{3}$ : Gs10; Drakensberg Foothill Moist Grassland, Gs12; East Griqualand Grassland.

Dimbaza (giant earthworms)

Underlying Lithology ${ }^{1}$ : Adelaide Subgroup; mudstone, subordinate sandstone.

Elevation ${ }^{2}:$ 500-700 m amsl

Climate $^{3}$ : MAP (717 mm), MAE (1778 mm), Al (0.40; Semi-arid), MAT (17.0), MFD (3).

Vegetation Types $^{3}$ : SVs7; Bisho Thornveld.

High Drakensberg Wetlands (freeze-thaw thufur features)

Underlying Lithology ${ }^{1}$ : Drakensberg Group Basalt.

Elevation ${ }^{2}: 3000-3200 \mathrm{~m}$ ams

Climate ${ }^{3}$ : MAP (707-737 mm), MAE (1289-1548 mm), Al (0.51; Dry subhumid), MAT $\left(4.0-9.6^{\circ} \mathrm{C}\right)$, MFD (96-158).

Vegetation Types ${ }^{3}$ : Gd8; Lesotho Highland Basalt Grassland, Gd10; Drakensberg Afroalpine Heathland.

${ }^{1}$ Lithology mapped in Figure 2 (CGS, 2017).

2Elevation range of wetlands mapped in Figure 2, from a $90 \mathrm{~m}$ SRTM DEM (Jarvis et al., 2008).

${ }^{3}$ Vegetation types and associated regional climate characteristics from Mucina and Rutherford (2006). MAP is mean annual precipitation, MAE is mean annual potential evaporation, $\mathrm{Al}$ is the UNEP (1997) aridity index (MAP/MAE) derived here from the Mucina and Rutherford (2006) data, MAT is mean annual temperature, MFD is mean annual number of frost days. and later discussion, as this is an area known for the development of large hummocks in seasonal wetland environments associated with the activity of giant earthworms (Fey, 2010). This area is located at a much lower elevation, and is slightly drier than the Drakensberg Foothills sites, but has a similar geology.

\section{Methods}

\section{Earthworm identification}

This paper was largely inspired by Kotze and O'Connor's (2000) observations of worm castings aggregated around plant stems on hummock surfaces, and by the discovery of earthworms in hummocks during 2007 fieldwork for Grenfell et al. (2009). Three earthworms were taken to Dr Plisko at the KwaZulu-Natal Museum in 2007, and were identified as Proandricus richerti (first described by Plisko, 2002). It is not known whether this is the only species to inhabit the hummocks, although the observation of large hummock development by giant earthworms identified as Proandricus skeadi in the Eastern Cape province (Fey, 2010; Figure 2) suggests that an adaptation to life in or around clay-rich gleyic soils (especially of the orthic Katspruit soil form; Fey, 2010) may be a feature of the genus Proandricus in general. The province of KwaZulu-Natal is a hotspot of earthworm diversity, and has 88 endemic species that are generally under threat from ongoing agricultural development and other land use change (Armstrong and Nxele, 2017).

\section{Field surveys and laboratory analysis}

Original observations of wetland geomorphology and hummock characteristics were recorded through automatic level survey and tape measurements in floodplain wetlands of the Nsonge River at Hlatikulu Vlei (Figure 3), and in a floodout wetland at Northington (Figure 4). These observations extend the previous accounts of wetland geomorphology published in Grenfell et al. (2008, 2009). Transect 1 extends from the terrestrial hillslope, through a zone of temporary wetland, a zone of seasonal wetland within a mature hummock field $(\mathrm{H} 1, \mathrm{H} 2)$, and into an abandoned channel of the Nsonge River (wetland zones delineated in the field based on Kotze and $\mathrm{O}^{\prime}$ Connor, 2000; Table II). Transects 2 and 3 extend from a floodplain alluvial ridge (temporary wetland), through seasonal wetland into an abandoned channel of the Nsonge River $(\mathrm{H} 3, \mathrm{H} 4, \mathrm{H} 5, \mathrm{H} 6)$, and represent areas of neo-formation of hummocks given that these sites were part of the active Nsonge River before channel abandonment through avulsion in 1984 (documented in Grenfell et al., 2009). It was reasoned that the existence of hummocks at these sites, currently well below the elevation at which thufur have been encountered, would refute an origin by freeze-thaw activity, and that selection of these sites would provide insight into the rate of hummock formation by earthworm activity. Further topographic and hummock morphological surveys were conducted at Hlatikulu Vlei in 2017 in the region of Transect 1 - the dimensions of 90 hummocks were sampled along transects extending from temporary to seasonal wetland zones. These surveys aimed to investigate the relationship between hummock dimensions and wetland zonation, as an indicator of potential hydrogeomorphic and vegetation drivers of earthworm behaviour.

Sediment cores were taken for radionuclide and $\mathrm{CHN}$ analysis through hummocks and the immediately adjacent hollows at sites $\mathrm{H} 1$ to $\mathrm{H} 6$, and during the topographic survey of a small floodout feature at Northington (sites NTF1 to NTF3; Figure 4). The floodout survey and chronology of sedimentation was 


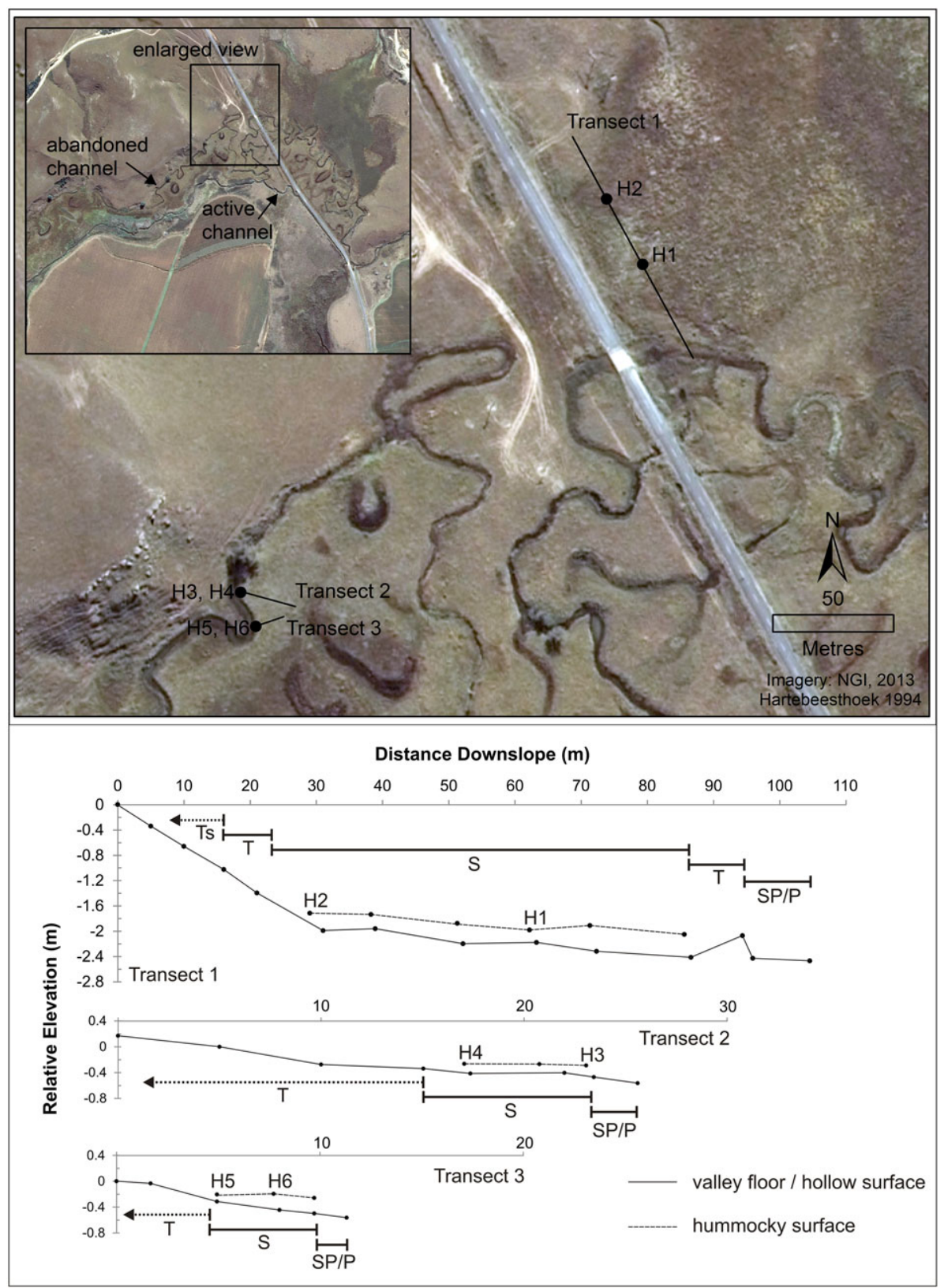

Figure 3. Field survey and core locations in a floodplain backswamp with mature clay hummock micro-topography (Transect 1 ), and an abandoned channel with neo-formation of clay hummocks (Transect 2, Transect 3); Nsonge River floodplain at Hlatikulu Vlei. Ts $=$ terrestrial hillslope, $\mathrm{T}=$ temporary wetland zone, $\mathrm{S}$ = seasonal wetland zone, $\mathrm{SP} / \mathrm{P}=$ semi-permanent to permanent wetland zone (zone descriptors after Kotze and $\mathrm{O}^{\prime} \mathrm{Connor}$, 2000; Table II). [Colour figure can be viewed at wileyonlinelibrary.com]

considered valuable to the study as a measure of comparison of rates of biogeomorphic hummock formation with rates of development of a locally-common physical geomorphological feature. This would provide some context for the relative importance of biogeomorphic processes in this setting. ${ }^{210} \mathrm{~Pb}$ alpha-geochronlogy was used to estimate sedimentation rates for the floodout cores, following a 'constant rate of supply' dating model (Appleby and Oldfield, 1978). This model was selected following observation of the ${ }^{210} \mathrm{~Pb}$ activity profiles, and given the likelihood of significant temporal variability in sediment sources and initial sediment alpha-activities (hillslope-surface sediment, channel-bed sediment, channel-bank sediment). Temporal variation in the activity of freshly-deposited floodout sediment precluded the application of an event-based dating model (Aalto and Nittrouer, 2012). In ${ }^{210} \mathrm{~Pb}$ alphageochronology, the activity of ${ }^{210} \mathrm{~Pb}$ is determined by counting the alpha activity of the ${ }^{210} \mathrm{Po}$ daughter. An acid extraction was used to leach mobile, exogenic ${ }^{210}$ Po from sediment grain surfaces. This ${ }^{210} \mathrm{Po}$ was then autoplated onto silver planchettes suspended in a solution of the leachate and dilute $\mathrm{HCl}$ (Nittrouer and Sternberg, 1981). Alpha-emission from the planchettes was then counted for 48-72 hours in Ortec alpha-spectrometers.

Carbon profiles and ${ }^{210} \mathrm{~Pb}$ activity profiles for cores from a stable (zero sediment flux) surface located on a level terrestrial hilltop adjacent to the Northington wetland (NTFB), the floodout cores, a hummock core (HUM1), and an adjacent hollow core (HOL1), were compared for the potential insight they would yield into sediment accumulation processes, and the role of earthworms, in hummock development. An automatic $\mathrm{CHN}$ analyser was used to measure total $\mathrm{C}$ and $\mathrm{N}$ content in four hummock-top worm castings, and four surface samples (upper $10 \mathrm{~cm}$ of the core profiles) for the six hummock/hollow sites surveyed ( $n=6$ sites $\times 4$ samples $=24$ for each feature; hummocks, hollows, castings). $\mathrm{C}$ and $\mathrm{N}$ content were not normally distributed; hence a Kruskal-Wallis test was used to investigate differences in $\mathrm{C}$ and $\mathrm{N}$ content for the three features sampled, to provide insight into the role of earthworms in hummock development and in regulatory ecosystem service provision within 


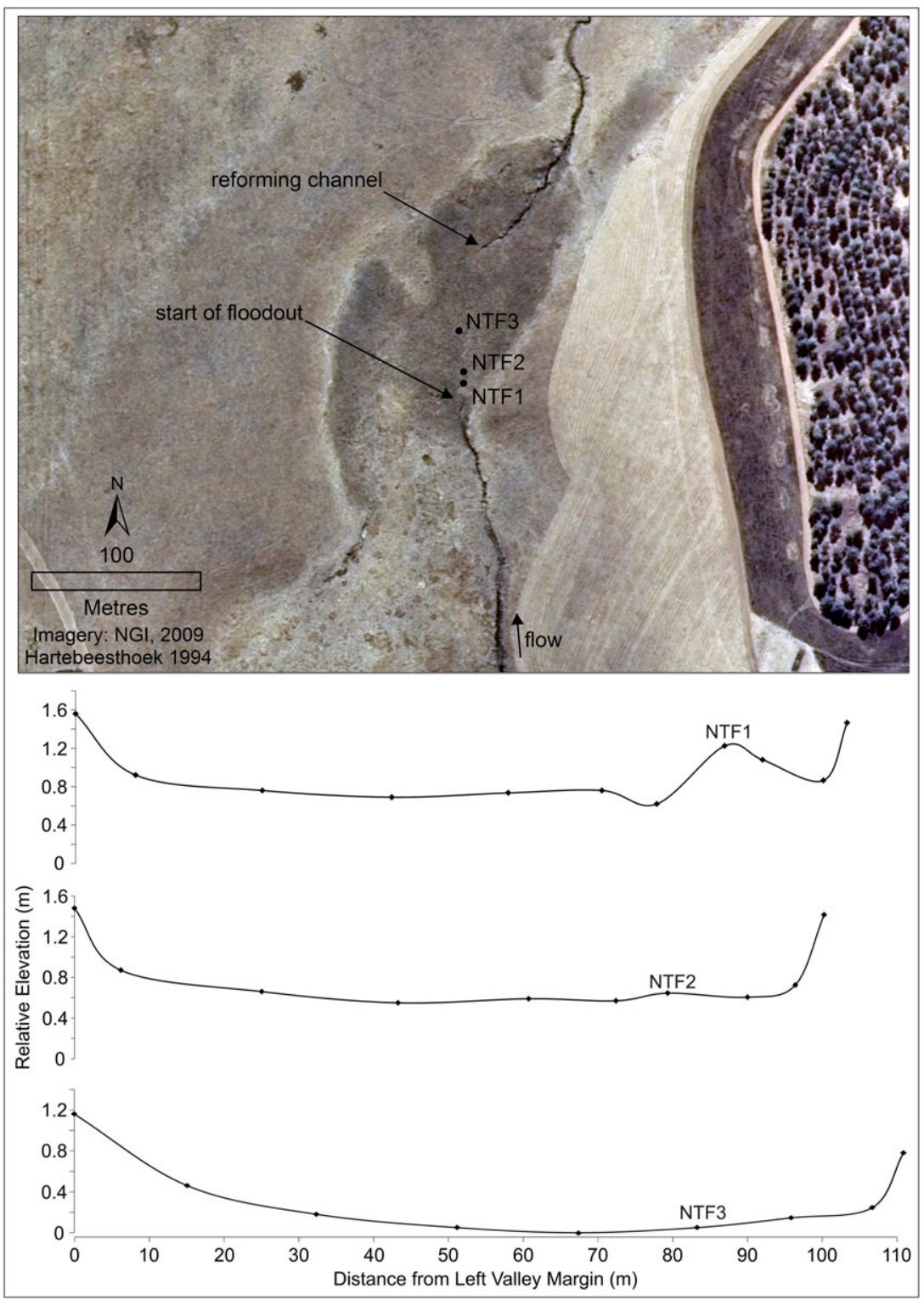

Figure 4. Field survey and core locations in a wetland floodout at Northington. [Colour figure can be viewed at wileyonlinelibrary.com]

these wetlands. All laboratory analyses were completed at the Sediment Research Facility at Exeter University in 2010.

\section{Results}

The clay hummocks investigated in this study have median dimensions of $0.3 \mathrm{~m}$ height, $0.6 \mathrm{~m}$ length, and $0.4 \mathrm{~m}$ width, giving a median volume of $0.1 \mathrm{~m}^{3}$ ( $n=90 ; 2017$ survey data). As observed by Fey (2010), the hummocks are relatively alike in form, and are regularly distributed, forming a reticulate pattern through areas of seasonal wetland where shallow (typically $<0.3 \mathrm{~m}$ in depth) surface waters accumulate for extended periods of time during the summer wet season (Figure 3). Hummocks are conspicuously absent from the natural levees of active and abandoned river channels, and from hillslopes adjacent to wetlands. They form on clay-rich substrates (and do not form on peat, or on sand-rich substrates).

Table II. Edaphic classification of wetland zones for eastern South Africa (adapted from Kotze and O'Connor, 2000)

\begin{tabular}{|c|c|c|c|c|}
\hline \multirow[b]{2}{*}{ Soil depth (mm) } & \multicolumn{4}{|c|}{ Degree of wetness/wetland zone } \\
\hline & Terrestrial & Temporary zone & Seasonal zone & Permanent/semi-permanent zone \\
\hline \multirow[t]{4}{*}{$0-100$} & Matrix chroma: generally $>3$ & Matrix chroma:1-3 & Matrix chroma: $0-2$ & Matrix chroma: $0-1$ \\
\hline & Few/no mottles & Few/no mottles & Many mottles & Few/no mottles \\
\hline & Low/medium OC & Low/medium OC & Medium OC & High OC \\
\hline & Non-sulphidic & Non-sulphidic & Seldom sulphidic & Often sulphidic \\
\hline \multirow[t]{2}{*}{$300-400$} & Matrix chroma: 2-3 & Matrix chroma: 0-2 & Matrix chroma: 0-2 & Matrix chroma: 0-1 \\
\hline & $\mathrm{No} /$ few mottles & Few/many mottles & Many mottles & Few/no mottles \\
\hline
\end{tabular}

High OC: soil organic carbon levels are greater than 5\%, often exceeding $10 \%$.

Low OC: soil organic carbon levels are less than $2 \%$.

Sulphidic soil material has sulphides present which yield a characteristic 'rotten egg' smell. 
Carbon profiles for a hummock/hollow core pair from the mature hummock field at Hlatikulu Vlei (Transect 1, Figure 3), and the floodout cores at Northington (Figure 4), provide insight into the nature of and controls on carbon accumulation processes in the wetlands studied (Figure 5). The floodout cores show an increase in near-surface carbon accumulation from the proximal to the distal part of the floodout (Figure 5), in association with declining clastic sedimentation rates (Figure 6) and a lowering of floodout relief that promotes locally-prolonged saturation (Figure 4). In contrast, near-surface carbon accumulation is greater in the raised-relief hummock feature than in the adjacent hollow (Figure 5), contrary to the trend of carbon accumulation increasing with hydroperiod (Ellery et al., 2009). The hollows are inundated more frequently and for a greater duration than hummocks, as indicated by the differences in vegetation composition observed on hummocks (grasses) and in hollows (sedges), yet carbon accumulation is greater in the hummocks.

Differences in $\mathrm{C}$ and $\mathrm{N}$ content for the hummocks, hollows and castings sampled are illustrated in Figure 7. C content differed significantly between the features (Kruskal-Wallis Test: $\left.\chi^{2}=27.298, \mathrm{df}=2, P<0.001\right)$. Casting samples had the highest $C$ content (median $C \%=4.69$ ), followed by hummock samples (median $\mathrm{C} \%=3.92$ ), and then hollow samples (median C $\%=2.23$ ). Similarly, $N$ content differed significantly between the features (Kruskal-Wallis Test: $\chi^{2}=30.373, \mathrm{df}=2$, $P<0.001$ ). Casting samples had the highest $\mathrm{N}$ content (median $\mathrm{N} \%=0.35$ ), followed by hummock samples (median $\mathrm{N} \%=$ 0.24 ), and then hollow samples (median $\mathrm{N} \%=0.14$ ). In summary, there is a systematic and statistically significant decline in $\mathrm{C}$ and $\mathrm{N}$ content from worm castings, to hummock surfaces, to hollow surfaces. In combination with the profile patterns observed in Figure 5 and described in the preceding paragraph, these data illustrate nodal accumulation of $\mathrm{C}$ and $\mathrm{N}$ within hummocks that can be explained by diffusion from worm castings preferentially excreted in the refuge provided by the vegetated and raised hummock environment.

The ${ }^{210} \mathrm{~Pb}$ profiles provide further evidence for biogeomorphic sediment accumulation and relief-building processes in the hummocks (Figure 6). Core NTFB from a non-erosion, non-deposition level hilltop shows meteoric cap development typical of a stable surface, while NTF1 and NTF2 are profiles typical of environments undergoing slow but active deposition (in this case associated with floodout development). There is clear evidence in the activity profile for HOL1 of removal of surface material from this hollow (no evidence of sediment accumulation, yet no meteoric cap development - the cap has been removed). This is not likely to be due to fluvial erosion, as the site is located in a backswamp depression that has not been fluvially active since 1984, and would before this time have been a site of very low fluvial energy (Grenfell et al., 2009). There is high surface activity of ${ }^{210} \mathrm{~Pb}$ in the hummock core HUM1, exceeding the activity associated with meteoric cap development. The average excess activity of 10 earthworm castings processed by the same protocol was 2.97 DPM/g, substantially higher than the surface activity maximum in NTFB and HUM 1. It is suggested here that the profiles observed in HOL1 and HUM1 are indicative of regular removal of high-activity surface material from the hollow environment through earthworm foraging, and casting of this material atop hummock surfaces following transformation in the earthworm gut (during which relative $\mathrm{C}$ and $\mathrm{N}$ enrichment also takes place). Earthworms may be able to forage in litter-rich hollows even when these environments are subject to shallow flooding, by keeping part of their length within the relatively betteroxygenated hummock (Fey, 2010).

Relationships between hummock height/hummock volume and wetland hydrogeomorphology are illustrated in Figure 8, where the survey 'datum' described refers to a level plane that extends across the wetland from the position on the hillslope

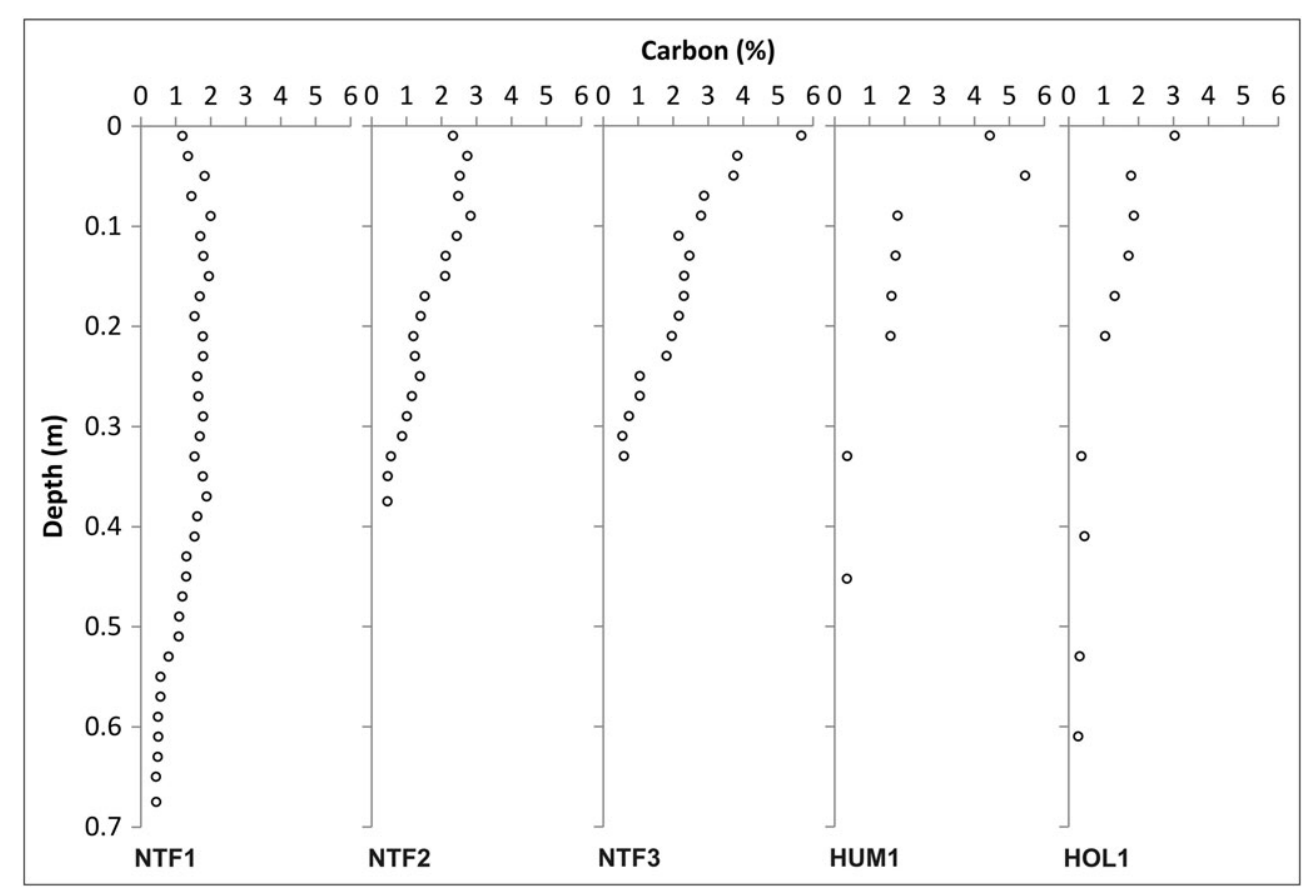

Figure 5. Carbon (\%) profiles from cores taken along the longitudinal axis of a wetland floodout (NTF1, NTF2, NTF3), a hummock core (HUM1), and an adjacent hollow core (HOL1). Core locations are indicated in Figures 3 and 4. Cores HUM1 and HOL1 are from site H1 in Figure 3, and are separated by $<1 \mathrm{~m}$. Note the increase in near-surface $\mathrm{C}$ accumulation from NTF1 to NTF2 to NTF3, following the change in relative elevation (and concomitant increase in the duration of saturation) from the raised floodout apex to the floodout toe. An apparent reverse association is evident from HOL1 to HUM1, where $\mathrm{C}$ is higher in the raised hummock feature than it is in the adjacent hollow (this is the case for all hummock/hollow pairs sampled). 


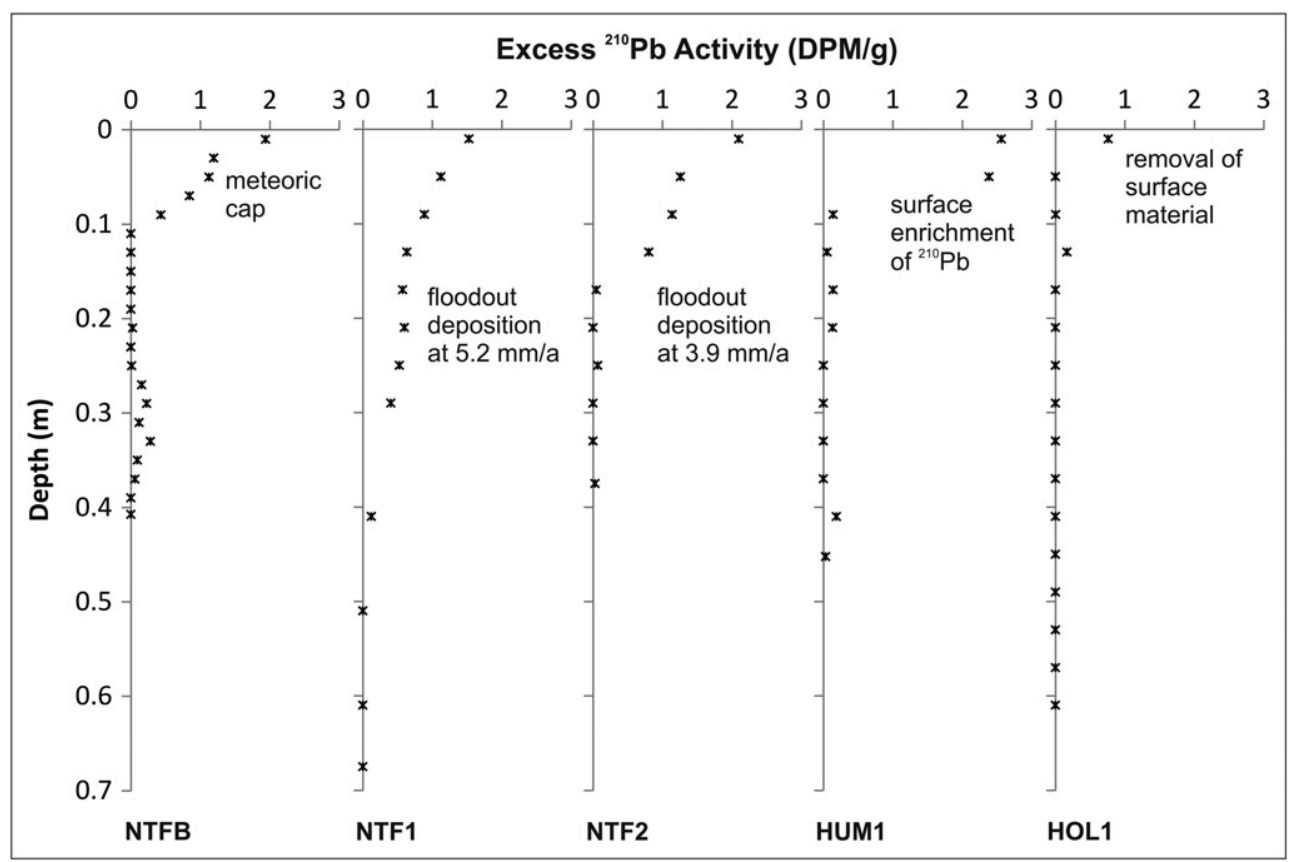

Figure 6. ${ }^{210} \mathrm{~Pb}$ activity profiles for cores from a stable (zero sediment flux) surface located on a level terrestrial hilltop adjacent to the Northington wetland (NTFB), sites of active clastic sediment deposition near a floodout head (NTF1, NTF2), a hummock (HUM1), and an adjacent hollow (HOL1). Profile interpretations are indicated in the figure and discussed further in the text. The sedimentation rate estimated for NTF3 (not illustrated) at the floodout toe was $2.1 \mathrm{~mm} / \mathrm{a}$. Site locations are indicated in Figures 3 and 4.

marking the contact between temporary and seasonal wetland (delineated according to Kotze and O'Connor, 2000; Table II). Hummocks first appear at the start of seasonal wetland, and tend to approach but never exceed a relatively planar surface at this elevation. This results in hummocks being taller and greater in volume in areas of deeper and more prolonged seasonal inundation. It is suggested that the relationships described here are a function of the hydrological constraint on hummock height enforced as hummocks approach the local temporary wetland elevation at which access to soil oxygen is secured. Worm energy is not expended building higher than this plane. The tendency to build relief to a common hydro-edaphic datum, which in reality varies locally across the wetland and is only approximated by the temporary/seasonal wetland boundary elevation at the hillslope base (Figure $8(B)$ ), results in grasses dominating on the extended temporary wetland surface marked by the hummock-top line, and sedges dominating in the hollows (as noted previously by Begg, 1989; Guthrie, 1996; and Kotze and $\mathrm{O}^{\prime}$ Connor, 2000).

\section{Discussion}

Formation of clay hummock micro-topography by earthworm activity

On the basis of the results presented, a conceptual model of hummock formation by earthworm activity is proposed in Figure 9. The origin of hummocks in this setting by freeze-thaw processes is discounted due to the absence of observable freeze-thaw activity in the wetlands studied, and the occurrence of similar features linked to earthworm activity at much lower elevations (with a much warmer climate) near Dimbaza (Table I, Figure 2). Evidence has been presented implicating earthworm activity in the development of clay hummock micro-topography. However, it is hydrogeomorphic processes that exert the initial control on local hydroperiod, by setting the initial relative elevation template (e.g. the slow development of an alluvial ridge that creates a backswamp area between the channel and hillside, or the sudden abandonment

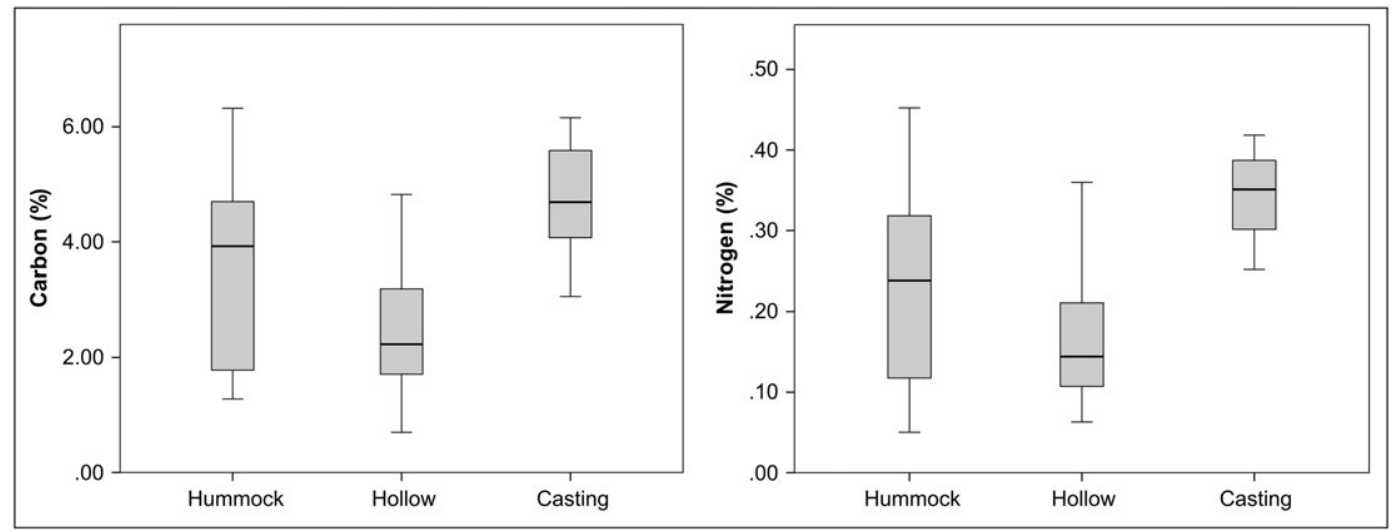

Figure 7. Comparison of carbon and nitrogen content in hummock and hollow surface samples, and hummock-top worm casting samples, from sites $\mathrm{H} 1$ to $\mathrm{H} 6$ (see Figure 3 for site locations). Casting samples have higher $\mathrm{C}$ and $\mathrm{N}$ content than hummock surface samples, which have higher $\mathrm{C}$ and $\mathrm{N}$ content that hollow surface samples. Differences in $\mathrm{C}$ and $\mathrm{N}$ content are statistically significant (see text for details). 


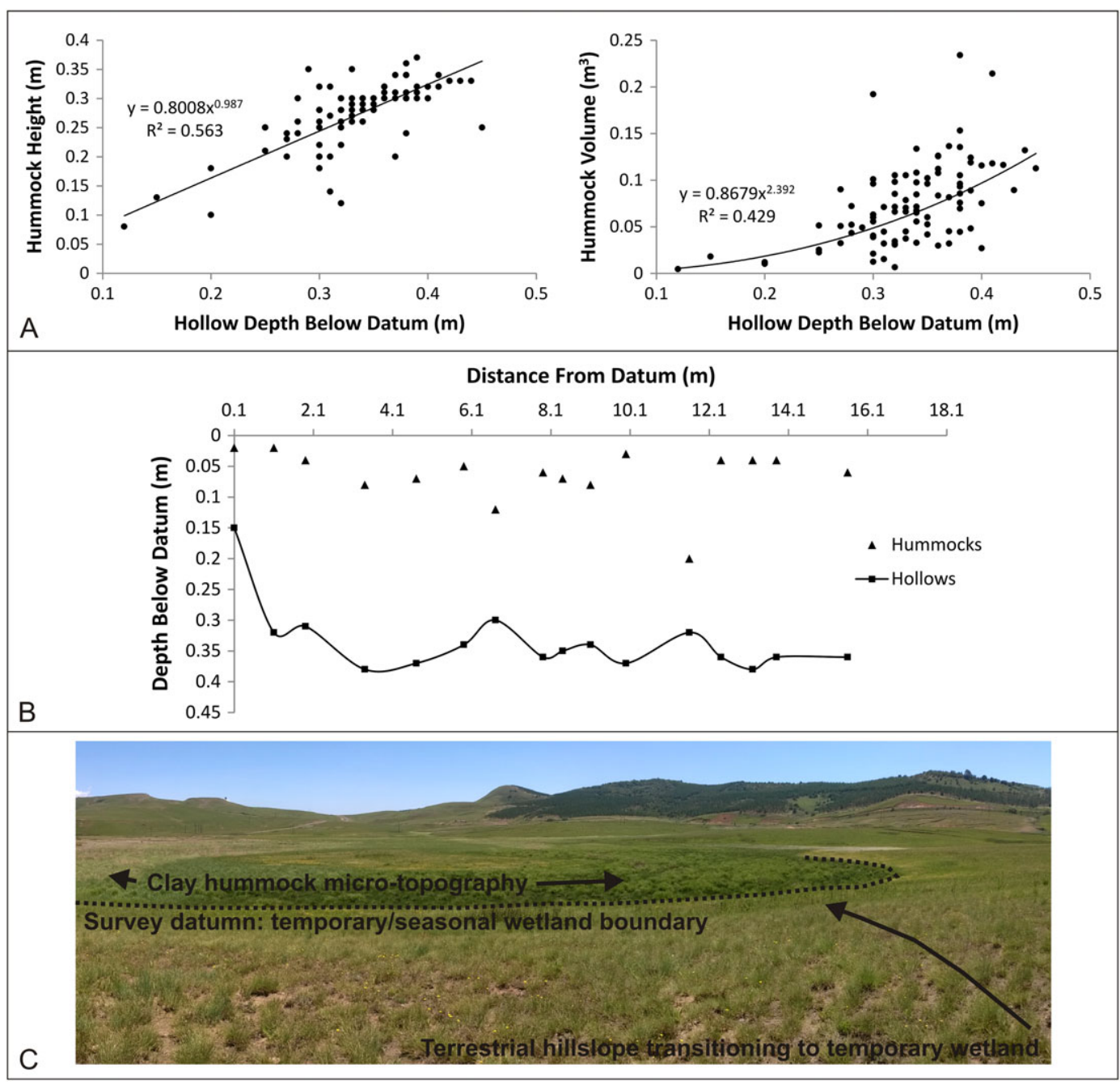

Figure 8. Best-fit power-functions of hummock dimensions with hollow depth below datum show that hummocks are both taller and greater in overall volume in deeper parts of the seasonal wetland area sampled at Hlatikulu Vlei $(A ; n=90)$, but do not protrude above the plane marking the boundary between temporary and seasonal wetland (the survey datum), and are typically built to a height of about $0.3 \mathrm{~m}+/-0.05 \mathrm{~m}$ above the local hollow (B; representing the typical relief that is broadly characteristic of all transects surveyed here). Landscape and survey attributes are illustrated in C. [Colour figure can be viewed at wileyonlinelibrary.com]

of a portion of river channel through avulsion, creating environments characterised by shallow seasonal inundation and more prolonged saturation). This template favours seasonal wetland plant species, such as Carex acutiformis, which form clumps in areas of seasonal wetland that become a focal point for casting activity (Figure 9, $\mathrm{t} 1$ ) due to the cover they afford to foraging earthworms. In addition to providing an initial anchor for casting amalgamation, these plants sustain wetland surface litter production necessary for earthworm survival.

Hummocks gradually grow in height and volume in accordance with available resources and the hydro-edaphic limitation of soil oxygen availability set by local water level variation, and will extend into areas of more prolonged inundation or saturation as earthworms take advantage of windows of opportunity that arise as water levels fall during periods of seasonal or more prolonged cyclical drought (Figure 9, t2). The water level fluctuation characteristic of seasonal wetlands in drylands (Tooth and McCarthy, 2007) is a necessary condition for earthworm biogeomorphic hummock development. Ultimately, through the work of earthworms there is a gradual 'terrestrialisation' (or shift along the continuum toward seasonal wetland) of formerly inundated environments, with grasses colonising hummock surfaces that approach the local elevation of temporary wetland, and the seasonal wetland hummock field extending further into the semi-permanent to permanent wetland zone, but always retaining the reticulation that allows for preferential flow of water and resources to the biological community.

It is proposed that the biomorphodynamic processes observed provide an example of energy conversion that leads to maximum entropy production through a pattern of efficient transport of mass (Kleidon, 2016; Savenije and Hrachowitz, 2017); (i) energy enters the biogeomorphic system through water flow and primary production by the characteristic vegetation assemblage, (ii) mass is transferred across a gradient during energy conversion by earthworm respiration, (iii) a reticulate pattern results that is self-reinforcing (Kleidon et al., 2013), creating an organised preferential flow network in the form of hummock micro-topography, and (iv) the pattern is entrenched in the local landscape (as in Zaitlin and Hayashi, 2012; Coombes and Viles, 2015). In this way, the earthworms are ecosystem engineers in that they have evolved a behaviour that enforces a pattern that ensures the persistence of an ecosystem that "tends to maximum efficiency for survival" (Savenije and Hrachowitz, 2017: 1110). Thus, the ecosystem is shaped by the hydrogeomorphic system, and through the coupling inherent in biomorphodynamics (Murray et al., 2008), the ecosystem shapes the hydrogeomorphic system, providing a mechanism for 'natural selection through biogeomorphic inheritance' as suggested by Corenblit et al. 


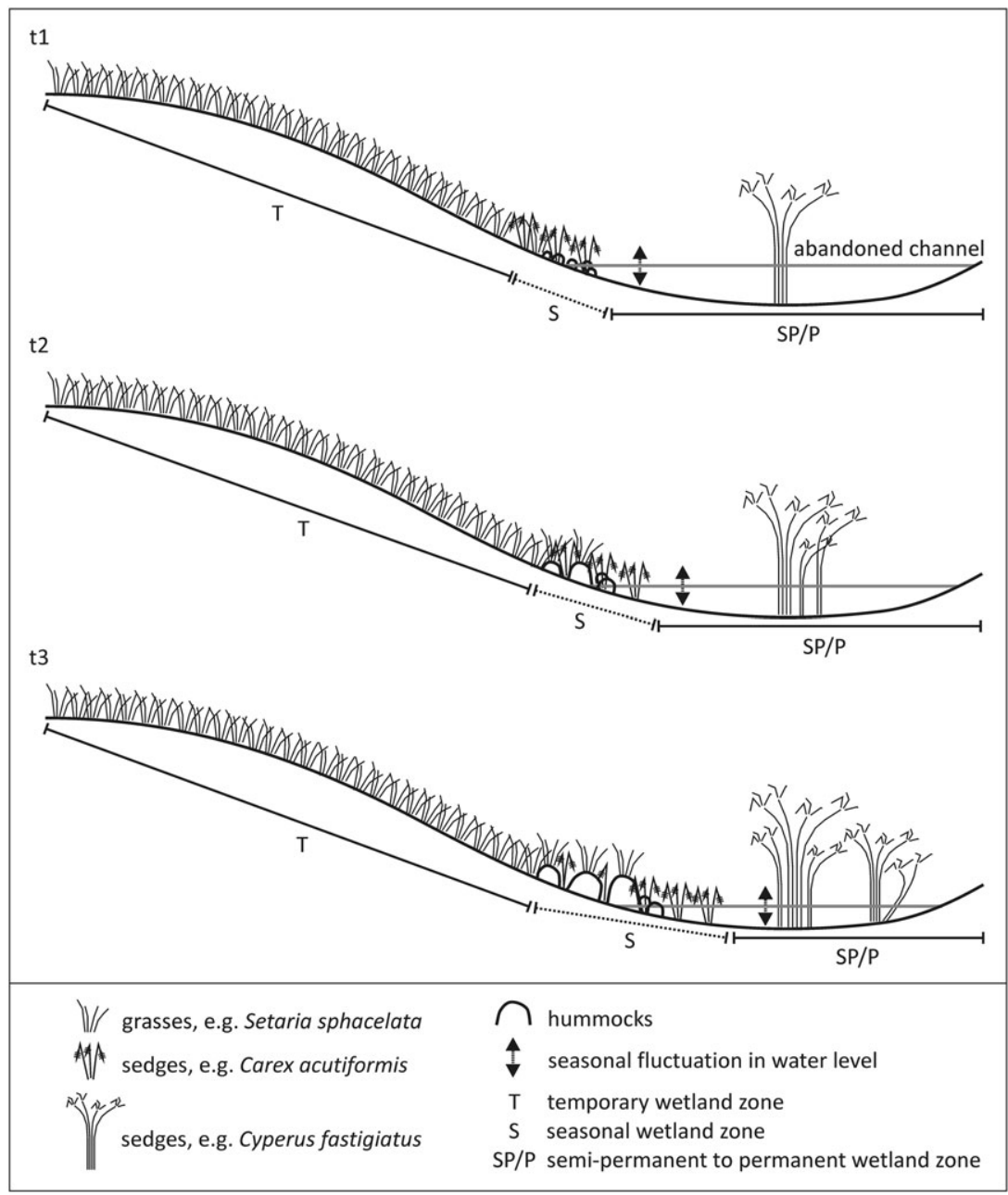

Figure 9. Conceptual model of the development of clay hummock micro-topography by earthworms in seasonal wetlands of the Drakensberg Foothills, in this case initiated by the provision of a new inundated area following river channel abandonment (e.g. Transects 2 and 3 in Figure 3). Even mature hummock fields can be re-shaped by earthworm activity following similar biogeomorphic processes, as has been observed in the wetland shown in Figure 8(C), as clumps of sedges such as Carex acutiformis establish in relatively more open hollows and are colonised by earthworms (Figure 10).

(2007: 2072). The above could be considered a mechanism for wetland resilience as well (as reviewed by Tooth, 2018), in that a change in hydrogeomorphic structure such as deep flooding following avulsion will in time be reverted to hummock micro-topography by the slow biomorphodynamics of earthworm activity. This resilience may be threatened by activities that affect earthworm persistence, such as water pollution (Plisko, 2002; Armstrong and Nxele, 2017).

\section{Further implications}

Since the median density of hummock core sub-samples determined during laboratory analysis was $1472 \mathrm{~kg} / \mathrm{m}^{3}$, a hummock of median dimensions ( $0.1 \mathrm{~m}^{3}$ volume) consists of $147.2 \mathrm{~kg}$ of fine sediment. Given median hummock $\mathrm{C}$ and $\mathrm{N}$ contents of $3.92 \%$ and $0.24 \%$ respectively, one can estimate a total carbon store of $5.8 \mathrm{~kg}$ and a total nitrogen store of $0.35 \mathrm{~kg}$ per hummock. In a $100 \mathrm{~m}^{2}$ area of seasonal wetland hosting a typical 36 hummocks $(0.1 \%$ the area of the mature hummock field pictured in Figure 3), the $\mathrm{C}$ and $\mathrm{N}$ store in hummocks alone equates to $208.8 \mathrm{~kg}$ and $12.6 \mathrm{~kg}$, respectively. These estimates, although based on fairly limited data, motivate for further research on the quantity and form of biogeochemically reactive elements stored in the wetland hummocks (Zhang et al., 2013 showed that some earthworm activity can lead to unequal amplification of carbon stabilisation compared with mineralisation). Further work is needed to elaborate on the mechanisms of element redistribution within these clay hummock systems, and to investigate other biogeochemical processes that have been shown to lead to biogeochemical 'hotspots' in wetland systems with micro-topographic variation (Frei et al., 2012). The estimates also encourage ongoing efforts to conserve not only the wetland areas hosting these earthworms, but also the catchments feeding the wetlands, to secure the survival of the earthworms and the ecosystem services they are providing through the biomorphodynamic interactions documented.

The median mass of a single casting, determined during laboratory analysis, was $2 \mathrm{~g}$. A median mature hummock therefore comprises about 73600 castings. Assuming a casting rate of 1 per earthworm per day, one could speculate a hummock development time (to maturity, for median dimensions and masses) of 201 years for a single earthworm, 100 years for 2 earthworms, or 67 years for 3 earthworms. The newly-formed hummocks on Transects 2 and 3 (Figure 3) had reached dimensions yielding a volume of about $0.008 \mathrm{~m}^{3}(10.6 \mathrm{~kg}$; 5300 castings), implying a hummock development time of 14 years for 1 earthworm at 1 casting per day, 7 years for 2 earthworms, and 4 years for 3 earthworms. The year of channel abandonment constrains the total development time in this setting to $2010-1984=26$ years, about double the time it would take 1 earthworm at 1 casting per day on the above calculations, which could suggest: (i) that the process of hummock building is seasonally or more regularly halted due to 


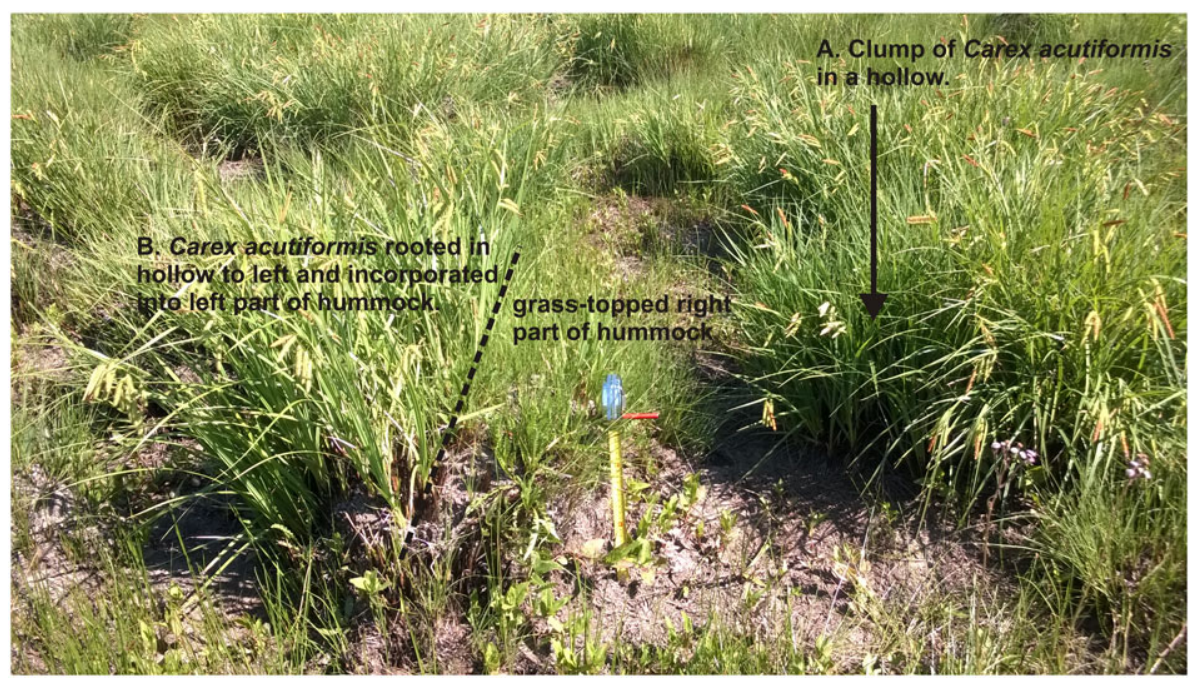

Figure 10. Ongoing hummock development in a mature hummock field at Hlatikulu Vlei, showing a low clump of Carex acutiformis (A) that does not yet appear to be worked by worms (lack of castings), and a hummock with one side comprising Carex acutiformis growing half in the adjacent hollow and half through the hummock, and the other side topped by grass (B). Once hummocks reach an elevation that approximates the local temporary wetland level, grazing of Carex or removal by fire could initiate the transition to a grass top. [Colour figure can be viewed at wileyonlinelibrary.com]

inundation and or cold temperatures (i.e. the process is affected by the duration of windows of opportunity, which will vary across a wetland according to the structure of the hydrogeomorphic template); and/or (ii) that hummock building is halted or slowed when the preferred height and volume for the resident earthworms are reached.

In comparison, assuming a median aggradation rate of $3.9 \mathrm{~mm} / \mathrm{a}$ (the intermediate floodout core sedimentation rate, which over the floodout surface area of $690 \mathrm{~m}^{2}$ equates to $\left.2.7 \mathrm{~m}^{3} / \mathrm{a}\right)$, development of the small floodout feature surveyed (approximate volume $=186 \mathrm{~m}^{3}$ ) has taken at least 70 years. At this rate, floodout processes would take the equivalent of 14 days at median aggradation to accumulate the equivalent volume of one hummock of median dimensions. Further data collection and quantification of rates of the processes described, within the framework proposed by Jones (2012), could lead to advances in understanding the dynamics and broader significance of the observed biogeomorphology and resulting landscape pattern, although the above case of floodout development illustrates how the relatively greater rate of physical sedimentation processes may drive initial variations in relative elevation that are subsequently re-shaped by the biomorphodynamics.

\section{Conclusions}

This paper contributes to the growing literature on wetlands in drylands (after Tooth and McCarthy, 2007) by highlighting the importance of understanding how biota that have adapted to challenging environmental conditions can interact with physical processes to shape these ecosystems and the regulatory services that they provide (Tooth et al., 2015a). In agreement with much of the wetlands in drylands literature, the paper emphasises the fundamental control of hydrogeomorphology on wetland biomorphodynamics, but also highlights ways in which the activity of biota can feed back to shape the hydrogeomorphology and biogeochemistry of wetlands (Thomas et al., 2014). Spatio-temporal variations in wetland hydroperiod are driven fundamentally by interactions between hydrology (surface and groundwater), hydraulics, and the structure and composition of the geomorphic setting (Brinson, 1993; Tooth et al., 2015b), but a complete understanding of wetland ecology is not possible without comprehensive analysis of the physical, biological and biogeomorphic processes that alter the magnitude and/or gradient of spatio-temporal variations in relative elevation in wetland environments (McCarthy and Hancox, 2000; Tooth and McCarthy, 2007). Further engagement between wetland ecologists, hydrogeomorphologists and biogeochemists through science that applies interdisciplinary methodologies may help to develop the full-system understanding of wetland in dryland morphodynamics and ecosystem service provision that is needed to manage these systems effectively, in a context of increasing pressures from development and environmental change.

Acknowledgements - This paper has been a product of many years of discussion, opportunistic fieldwork, and tinkering, and the first author would like to thank the co-authors for their patience in this regard. Thanks to Stephen Tooth, Spike McCarthy, Donovan Kotze and Warren Botes for interesting and formative discussions in the field during the early stages of development of the ideas incorporated in the paper. Thanks to Dr Plisko of the KwaZulu-Natal Museum for identifying earthworm specimens. We are grateful to Mr Steyn (Forest Lodge), Mr Botha (Northington), and Ezemvelo KZN Wildlife, for providing access to their land. The work was funded at various stages by the South African Water Research Commission, Exeter University, and the University of the Western Cape.

\section{References}

Aalto R, Nittrouer CA. 2012. ${ }^{210} \mathrm{~Pb}$ geochronology of flood events in large tropical river systems. Philosophical Transactions of the Royal Society A 370: 1-35. https://doi.org/10.1098/rsta.2011.0607.

Appleby G, Oldfield F. 1978. The calculation of lead-210 dates assuming a constant rate of supply of unsupported $\mathrm{Pb}-210$ to the sediment. Catena 5: 1-8. https://doi.org/10.1016/S0341-8162(78)80002-2.

Armstrong AJ, Nxele TC. 2017. English names of the megadrile earthworms (Oligochaeta) of KwaZulu-Natal. African Invertebrates 58: 11-20. https://doi.org/10.3897/Afrlnvertebr.58.13226.

Barot S, Ugolini A, Brikci F. 2007. Nutrient cycling efficiency explains the long-term effect of ecosystem engineers on primary production. Functional Ecology 21: 1-10. https://doi.org/10.1111/j.13652435.2006.01225.x.

Begg GW. 1989. The Wetlands of Natal (Part 3). The location, status and functioning of the priority wetlands of Natal. Natal Town and Regional Planning Report 73. 
Brinson MM. 1993. A Hydrogeomorphic Classification for Wetlands. US Army Corps of Engineers Technical Report WRP-DE-4.

CGS. 2017. 1:1 000000 Geological Data. South African Council for Geoscience. Available online at http://www.geoscience.org.za/index.php/publication/downloadable-material (accessed 6/2/2018).

Coggan NV, Hayward MW, Gibb H. 2018. A global database and 'state of the field' review of research into ecosystem engineering by land animals. Journal of Animal Ecology 87: 974-994. https://doi.org/ 10.1111/1365-2656.12819.

Coombes MA. 2016. Biogeomorphology: diverse, integrative and useful. Earth Surface Processes and Landforms 41: 2296-2300. https:// doi.org/10.1002/esp.4055.

Coombes MA, Viles HA. 2015. Population-level zoogeomorphology: the case of the Eurasian badger (Meles meles L.). Physical Geography 36: 215-238. https://doi.org/10.1080/02723646.2015.1026170.

Corenblit D, Davies NS, Steiger J, Gibling MR. Bornette G. 2015. Considering river structure and stability in the light of evolution: feedbacks between riparian vegetation and hydrogeomorphology. Earth Surface Processes and Landforms 40: 189-207. https://doi.org/ 10.1002/esp.3643

Corenblit D, Steiger J, Gurnell A, Tabacchi E. 2007. Darwinian origin of landforms. ESEX Commentary. Earth Surface Processes and Landforms 32: 2070-2073. https://doi.org/10.1002/esp.1536.

Darwin CR. 1881. The Formation of Vegetable Mould, through the Action of Worms, with Observations on their Habits. John Murray: London.

Davies NS, Gibling MR. 2011. Evolution of fixed-channel alluvial plains in response to Carboniferous vegetation. Nature Geoscience 4: 629-633. https://doi.org/10.1038/ngeo1237.

Downing BH. 1966. The Plant Ecology of Thabamhlope Vlei. Unpublished MSc Thesis: University of Natal, Pietermaritzburg.

Eldridge DJ, Bowker MA, Maestre FT, Alonso P, Mau RL, Papadopoulos J, Escudero A. 2010. Interactive effects of three ecosystem engineers on infiltration in a semi-arid Mediterranean grassland. Ecosystems 13: 499-510. https://doi.org/10.1007/s10021-010-9335-4.

Ellery W, Grenfell M, Grenfell S, Kotze D, McCarthy TS, Tooth S, Grundling PL, Beckedahl H, Le Maitre D, Ramsay L. 2009. WET-Origins: Controls on the Distribution and Dynamics of Wetlands in South Africa. Water Research Commission Research Report TT33409, Pretoria.

Fey M. 2010. Soils of South Africa. Cambridge University Press: Cape Town.

Frei S, Knorr KH, Peiffer S, Fleckenstein JH. 2012. Surface microtopography causes hot spots of biogeochemical activity in wetland systems: a virtual modeling experiment. Journal of Geophysical Research 117 G00N12. https://doi.org/10.1029/2012JG002012.

Grab SW. 1994. Thufur in the Mohlesi Valley, Lesotho, Southern Africa. Permafrost and Periglacial Processes 5: 111-118. https://doi.org/ 10.1002/ppp.3430050205.

Grenfell MC, Ellery W, Grenfell SE. 2008. Tributary valley impoundment by trunk river floodplain development: a case study from the KwaZulu-Natal Drakensberg Foothills, eastern South Africa. Earth Surface Processes and Landforms 33: 2029-2044. https://doi.org/ 10.1002/esp.1652.

Grenfell MC, Ellery WN, Grenfell SE. 2009. Valley morphology and sediment cascades within a wetland system in the KwaZulu-Natal Drakensberg Foothills, eastern South Africa. Catena 78: 20-35. https://doi.org/10.1016/j.catena.2009.02.004.

Grenfell SE, Ellery WN, Grenfell MC, Ramsay LF, Flügel TJ. 2010. Sedimentary facies and geomorphic evolution of a blocked-valley lake: Lake Futululu, northern Kwazulu-Natal, South Africa. Sedimentology 57: 1159-1174. https://doi.org/10.1111/j.1365-3091.2009.01141.x.

Guthrie IA. 1996. Aspects of the structure and functioning of the vegetation of the Hlatikulu Vlei. Unpublished MSc Thesis: University of Natal, Pietermaritzburg.

Jarvis A, Reuter HI, Nelson A, Guevara E. 2008. Hole-filled SRTM for the globe Version 4. Available from the CGIAR-CSI SRTM 90m Database (http://srtm.csi.cgiar.org).

Jones CG. 2012. Ecosystem engineers and geomorphological signatures in landscapes. Geomorphology 157-158: 75-87. https://doi. org/10.1016/j.geomorph.2011.04.039.

Jones CG, Lawton JH, Shachak M. 1994. Organisms as ecosystem engineers. Oikos 69: 373-386. https://doi.org/10.2307/3545850.
Jones CG, Lawton JH, Shachak M. 1997. Positive and negative effects of organisms as physical ecosystem engineers. Ecology 78: 1946-1957. https://doi.org/10.1890/0012-9658(1997)078[1946: PANEOO]2.0.CO;2.

Jouquet P, Dauber J, Lagerlöf J, Lavelle P, Lepage M. 2006. Soil invertebrates as ecosystem engineers: intended and accidental effects on soil and feedback loops. Applied Soil Ecology 32: 153-164. https:// doi.org/10.1016/j.apsoil.2005.07.004.

Kleidon A. 2016. Thermodynamic Foundations of the Earth System. Cambridge University Press: Cambridge.

Kleidon A, Zehe E, Ehret U, Scherer U. 2013. Thermodynamics, maximum power, and the dynamics of preferential river flow structures at the continental scale. Hydrology and Earth System Sciences 17: 225-251. https://doi.org/10.5194/hess-17-225-2013.

Kotze DC, O'Connor TG. 2000. vegetation pattern within and among palustrine wetlandsalong an altitudinal gradient in KwaZulu-Natal, South Africa. Plant Ecology 146: 77-96. https://doi.org/10.1023/ A:1009812300843.

Longmore JL. 2001. The geomorphology of wetlands in the upper Mooi River catchment. Unpublished MSc Thesis, University of Natal, Pietermaritzburg: KwaZulu-Natal.

McCarthy TS, Ellery WN, Bloem A. 1998. Some observations on the geomorphological impact of hippopotamus (Hippopotamus amphibious L.) in the Okavango Delta, Botswana. African Journal of Ecology 36: 44-56. https://doi.org/10.1046/j.13652028.1998.89-89089.x.

McCarthy TS, Hancox PJ. 2000. Wetlands. In The Cenozoic of Southern Africa, Partridge TC, Maud RR (eds). Oxford Monographs on Geology and Geophysics. Oxford University Press: Oxford; 218-235.

Mitsch WJ, Gosselink JG. 2008. Wetlands, 4th edn. Wiley: Hoboken.

Mucina L, Rutherford MC. 2006. The Vegetation of South Africa, Lesotho and Swaziland. South African National Biodiversity Institute: Pretoria.

Murray AB, Knaapen MAF, Tal M, Kirwan ML. 2008. Biomorphodynamics: physical-biological feedbacks that shape landscapes. Water Resources Research 44 W11301. https://doi.org/ 10.1029/2007WR006410.

Nittrouer CA, Sternberg RW. 1981. The formation of sedimentary strata in an allochthonous shelf environment: The Washington Continental Shelf. Marine Geology 42: 210-232. https://doi.org/10.1016/00253227(81)90164-X.

Plisko JD. 2002. Nine new earthworm species of Proandricus Plisko, 1992 from South Africa and Lesotho (Oligochaeta: Microchaetidae). African Invertebrates 43: 183-203.

Reinhardt L, Jerolmack D, Cardinale BJ, Vanacker V, Wright J. 2010. Dynamic interactions of life and its landscape: feedbacks at the interface of geomorphology and ecology. Earth Surface Processes and Landforms 35: 78-101. https://doi.org/10.1002/esp.1912.

Savenije HG, Hrachowitz M. 2017. HESS Opinions "Catchments as meta-organisms - a new blueprint for hydrological modelling". Hydrology and Earth System Sciences 21: 1107-1116. https://doi. org/10.5194/hess-21-1107-2017.

Sieben EJJ, Morris CD, Kotze DC, Muasya AM. 2010. Changes in plant form and function across altitudinal and wetness gradients in the wetlands of the Maloti-Drakensberg, South Africa. Plant Ecology 207: 107-119. https://doi.org/10.1007/s11258-009-9657-5.

Thomas AD, Dougill AJ, Elliott DR, Mairs H. 2014. Seasonal differences in soil $\mathrm{CO}_{2}$ efflux and carbon storage in Ntwetwe Pan, Makgadikgadi Basin, Botswana. Geoderma 219-220: 72-81. https://doi.org/ 10.1016/j.geoderma.2013.12.028.

Tooth S. 2018. The geomorphology of wetlands in drylands: Resilience, nonresilience, or ... ? Geomorphology 305: 33-48. https://doi.org/ 10.1016/j.geomorph.2017.10.017.

Tooth S, Brandt D, Hancox PJ, McCarthy TS. 2004. Geological controls on alluvial river behaviour: a comparative study of three rivers on the South African Highveld. Journal of African Earth Science 38: 79-97. https://doi.org/10.1016/j.jafrearsci.2003.08.003.

Tooth S, Ellery F, Grenfell M, Thomas A, Kotze D, Ralph T. 2015b. 10 Reasons why the Geomorphology of Wetlands is important. Wetlands in Drylands Research Network/Climate Change Consortium of Wales, 32. Available online at http://wetlandsindrylands.net/ (accessed 6/2/2018). 
Tooth S, Grenfell MC, Thomas A, Ellery WN. 2015a. Wetlands in Drylands: 'Hotspots' of Ecosystem Services in Marginal Environments. GSDR 2015 Science Brief, United Nations.

Tooth S, McCarthy TS. 2007. Wetlands in drylands: key geomorphological and sedimentological characteristics, with emphasis on examples from southern Africa. Progress in Physical Geography 31 3-41. https://doi.org/10.1177/0309133307073879.

Tooth S, McCarthy TS, Brandt D, Hancox PJ, Morris R. 2002. Geological controls on the formation of alluvial meanders and floodplain wetlands: the example of the Klip River, eastern Free State, South Africa. Earth Surface Processes and Landforms 27: 797-815. https:// doi.org/10.1002/esp.353.

Travers SK, Eldridge DJ. 2016. Does litter decomposition vary between the foraging pits of two soil-disturbing mammal species? Earth Surface Processes and Landforms 41: 669-676. https://doi.org/10.1002/ esp.3892.

UNEP. 1997. In World Atlas of Desertification, Middleton N, Thomas D (eds) , 2nd edn. Edward Arnold: London.s
Vrieling A, Sterk G, de Jong SM. 2010. Satellite-based estimation of rainfall erosivity for Africa. Journal of Hydrology 395: 235-241. https://doi.org/10.1016/j.jhydrol.2010.10.035.

Whitesides CJ, Butler DR. 2015. Biopedoturbation and zoogeomorphology - an introduction to the special issue. Physical Geography 36: 177-177. https://doi.org/10.1080/ 02723646.2015 .1035627$.

Whitesides CJ, Butler DR. 2016. Bioturbation by gophers and marmots and its effects on conifer germination. Earth Surface Processes and Landforms 41: 2269-2281. https://doi.org/10.1002/esp.4046.

Zaitlin B, Hayashi M. 2012. Interactions between soil biota and the effects on geomorphological features. Geomorphology 157-158 142-152. https://doi.org/10.1016/j.geomorph.2011.07.029.

Zhang W, Hendrix PF, Dame LE, Burke RA, Wu J, Neher DA, Li J, Shao Y, Fu S. 2013. Earthworms facilitate carbon sequestration through unequal amplification of carbon stabilization compared with mineralization. Nature Communications 4: 2576. https://doi.org/10.1038/ ncomms3576. 